Бојан М. Ђорђевић

Универзитет у Београду

Филолошки факултет

e-mail: nalesko1965@gmail.com
050:316.75 ПРОГРЕС

https://doi.org/10.18485/ai_lik.2020.6.9.1

Оригинални научни рад

\title{
КАД СУ КОНТРАРЕВОЛУЦИОНАРИ ПРИЗИВАЛИ \\ РЕВОЛУЦИЈУ: КУЛТУРНИ ДИСКУРС ДНЕВНОГ ЛИСТА ПРОГРЕС (1920)
}

У раду се анализира културни дискурс у политичком дневном листу Проірес, који је излазио током шест месеци (од маја до новембра) 1920. године, а чији је власник био Сима Пандуровић, те уредници Драгиша Васић, и једно време Душан С. Николајевић. Указује се на еклектицизам идеолошких, светоназорских и поетичких ставова и стремљења, као и на то да је тај лист окупио најразличитије представнике тадашњег културног и књижевног живота Срба и Хрвата.

Кључне речи: Проіррес, књижевност, политика, идеологија, револуција, поетика, полемика.

1.

Када бисмо на једном месту донели списак српских и хрватских књижевника и културних радника који чине: Сима Пандуровић, Драгиша Васић, Душан Николајевић, Тодор Манојловић, Тин Ујевић, Милош Црњански, Ратко Парежанин, Станислав Винавер, Станислав Краков, Синиша Кордић, Светислав Стефановић, Ранко Младеновић, Растко Петровић, Бошко Токин, Сибе Миличић - тешко бисмо могли избећи примедбе за недопустиви еклектицизам, за произвољно повезивање књижевника који су и својим животом, и својим светоназорима, и својим поетикама у много чему различити, а често и антиподи. Могло би се, штавише, даље рећи да би се њихова имена, овако скупно 
узета, могла наћи једино у каквој антологији, па и онда би се приређивач такве антологије могао оптужити за некритичност и недостатак доследног критеријума.

Па ипак, у једном тренутку, током шест месеци, од маја до новембра 1920. године, сви ови књижевници заиста су се нашли заједно, окупљени око дневног листа који је утемељен као независно политичко гласило, али који је од почетка имао много већи утицај на културни живот у тек формираној и још до краја неуобличеној Краљевини Срба, Хрвата и Словенаца. Уосталом, управо то што су прилике у земљи биле још увек несређене, што се водила полемика о карактеру власти и државне организације, о политичком устројству - све то је омогућило да постоји, макар и накратко, овакав лист који ће, упркос основама уређивачке политике и главном тону, постати место слободног сучељавања различитих ставова о најразноврснијим питањима политичког и културног живота. Само у таквим околностима, и са овако широком лепезом углавном млађих сарадника, могла се и нападати и бранити државна политка, и славити и осуђивати Октобарска револуција, и заступати и оштро критиковати модернизам у књижевности и уметности, а о истим књижевним текстовима писати и афирмативно и негаторски.

\section{2.}

Дневни лист Проірес покренули су у мају 1920. године (први број изашао је 10. маја) Сима Пандуровић, Драгиша Васић и Душан С. Николајевић. Номинално, власник је био Пандуровић, а Васић и Николајевић уредници, али су сва тројица имали финансијски удео у листу. Оно што их је повезивало јесте то што су сва тројица били књижевници, и сва тројица опозиционо настројени према тадашњој влади. Но, оно што их је разликовало били су њихови светоназори у том тренутку. У то доба, непосредно по Првом светском рату, Васић се истицао својим левичарским идејама, са изразитим симпатијама за совјетску власт, те апострофирањем радничке класе као силе која новој држави може обезбедити 
стабилност и напредак: „Ми смо досад имали срце Рата. Сад нам треба срце Рада. Дајмо друга срца деци. ${ }^{11}$

Душан С. Николајевић, пак, иступао је са изразито конзервативних позиција, и кад је у питању био однос према социјалистичком покрету и руској револуцији, и када се радило о модерном књижевном изразу. Иако је заступао став да је тадашњи друштвени систем, нарочито у светлу тек завршеног рата, неодржив, и да представља опасност за опстанак нове, младе државе, спасје видео искључиво „у дубоком и свестраном реформисању“, истичући: „Противници смо комунизма, и као економске и као политичке доктрине. “2 Лењина је видео као „повампиреног Брута“, а владавину бољшевика као „оличени макијавелизам“.”․ Истичући, у програмском тексту Криза Евройе, да је прогрес „увек одмерен и спор“, бољшевизам му се указивао као „чисто доктринарство“ и као наставак руске царистичке, деспотске традиције: „Свиреп је бољшевизам као и царизам, и у Владимиру Илићу Лењину има доследности злочина, снаге Петра Великог, крвавог лудаштва Ивана Грозног."“ Лењиново „обоготворење“, како га је назвао, критиковао је са изразито индивидуалистичког становишта, али је у тој критици култа вође неприкривено алудирао и на Николу Пашића, чиме је поље критике проширио и на домаћу политику: „То је један култ сасвим осредњим појединцима и један култ простачки, вулгаран, култ у коме се скрио егоизам, ситан интерес. ${ }^{\text {"5 }}$ У својим књижевним освртима, пак, Николајевић се исказивао као доследни антимодерниста и традиционалиста, чији су параметри за стил и правац у литератури били Гете, Ла Рошфуко и Богдан Поповић. ${ }^{6}$

Сима Пандуровић, који је, као номинални власник, давао тон овом политичком гласнику и често писао уводнике, био је ближи Николајевићу по својим идеолошким ставовима, али

Драгиша Васић, „Религија рада“, Проі̄pec, 1920, I, 7, 1.

2 Д. С. Николајевић, „Демократија и економија“, Проірес, 1920, I, 4, 1.

3 Д. С. Николајевић, „Брут и макијавелизам“, Проїрес, 1920, I, 3, 1.

4 Душан С. Николајевић, „Криза Европе“, Проірес, 1920, I, 11, 1.

5 Д. С. Н., „Култ личностима“, Проірес, 1920, I, 10, 1.

6 Видети: Душан С. Николајевић, „Ла Рошфуко - једна задоцнела импресија“, Проірес, 1920, I, 5, 2; Душан С. Николајевић, „Гетеов Вертер“, Проірес, 1920, I, 6, 1-2. 
се држао умерено и опрезно. Према бољшевичкој револуцији био је уздржан, али је није отворено нападао, сем у једној ствари. Наиме, највећу опасност видео је у бољшевичком плану за федерализацију државе. У критици федеративног уређења био је доследан и непоколебљив, видевши у томе опасност и за тек формирану Краљевину СХС: „Федерализам јемржња на државу, на напредак, на великукултуру и развијен

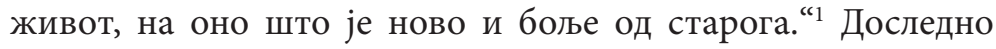
томе, иако жесток критичар Пашића, Трумбића и Веснића, залажући се за слободне изборе и Конституанту, подржавао их је једино у захтеву за централистичким уређењем државе. ${ }^{2}$ Извор овом опредељењу можда треба тражити у нечему што у то доба уједињења није било ни лако, ни популарно, а ни политички коректно изрећи, а то је Пандуровићева сумња у неопходност уједињења и у праве мотиве за то. Док је сва политичка и културна јавност истицала да уједињење представља остварење вишевековног сна југословенских народа на коме су радили најумнији српски, хрватски и словеначки политичари, научници и књижевници, дотле је Пандуровић сматрао да је стварање јединствене државе резултат међународних околности и тренутних политичких интереса великих сила: „Дело уједињења наших племена претежно је производ њиховог националног инстинкта и нужности спољашњих чињеница, резултат крви и зноја маса и међународних прилика, а не планова или прегнућа, смишљеног и систематског рада и приуготовљавања или памети њихових вођа.“" Како је овај текст био уводник првога броја Проїреса, он се може схватити и као програмско опредељење власника и уредништва. Стога је Пандуровић поставио једну наизглед парадоксалну поставку по којој

1 Сима Пандуровић, „Федерализам“, Проірес, 1920, I, 18, 1.

2 Сима Пандуровић, „Против провизориума“, Проірес, 1920, I, 2, 1.

3 С. П., „У име прогреса“, Проірес, 1920, I, 1, 1. Касније ће Пандуровић еволуирати у огорченог противника југословенске заједнице, чему ће до краја дати одушка у јеку окупације током Другог светског рата, упозоравајући: „Ако вам неко приступа као „Југословен“, можда је то и какав фантаст. Будите, у сваком случају, обазриви. Јер је много вероватније да је то или глупак или варалица.“ Сима Пандуровић, „Унутрашње оријентације“, Срйски нароg, 1944, III, 2/3, 16. 
„уједињењу треба да претходи разједињење“, одмах потом јасно објаснивши шта се под тим подразумева, то јест да се Срби, Хрвати и Словенци могу истински духовно ујединити тек кад се „разједине са својим нечасним политичарима, дотрајалим и реакционарним странкама. “4

Пандуровићеви ставови о књижевности и књижевној политици које је он износио у Проіресу готово да досад нису узимани у обзир када се говорило о његовом критичком ангажману. ${ }^{5}$ Узимало се да његова поратна књижевна и критичка делатност отпочиње у Мисли, а занемарује се да је Проірес био, како смо показали, управо Пандуровићев лист. Први програмски текст он је зато објавио управо у Проіресу, под називом Преg новом књижевношћу. ${ }^{6}$ То је изузетно озбиљна и прецизно изведена анализа стања српске књижевности након Великог рата, предочена мирним тоном и без иикакве острашћености. Пандуровић је најпре истакао погубан утицај рата на нашу књижевност: „Направљена је једна велика провалија и изгубљен континуитет.“ Затим са пијететом помиње мртве књижевнике, попут Велимира Рајића, Милутина Ускоковића, Диса и Милутина Бојића, указавши, међутим, и на оне „који су из ових или оних разлога ућутали“ (Дучић, Шантић, Р Ракић, Вељко Петровић, Ћипико, Бора Станковић). Наду у обнову и „буђење“ српске књижевности пружали су му, међутим, млађи, „талентовани“ писци, а њихов списак доказује да Пандуровић бар у том тренутку није био ускогруд, нити је показивао особине

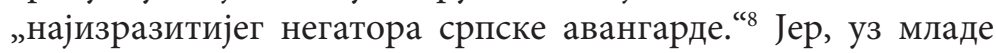
књижевнике склоне традиционалистичком стилу и маниру (Божа Стојадиновић, Света Миленовић, Синиша Кордић,

4 Сима Пандуровић, „Уједињење - разједињење“, Проірес, 1920, I, 60, 1.

5 Чак ни удетаљној анализи Пандуровићевих естетичких и поетичких ставова нису узимани у обзир текстови објављени у Проіресу. Видети: Gojko Tešić, Srpska avangarda u polemičkom kontekstu, Svetovi, Institut za književnost i umetnost, Novi Sad, Beograd, 1991, 61-83.

6 Проїрес, 1920, I, 59, 2-3.

7 Управо ће у Проіресу Пандуровић објавити свој познати есеј о Шантићевој поезији. Видети: С. Пандуровић, „Алекса Шантић“, Проїрес, 1920, I, 23, 2; 24, 2.

8 Г. Тешић, нав. дело, 62. 
Драгољуб Филиповић, па и најмлађа од свих, Десанка Максимовић), Пандуровић је истакао и најзвучнија имена „младих“ са другог поетичког и естетичког пола - Иво Андрић, Милош Црњански, Сибе Миличић, Станислав Винавер. Ако, дакле, и има елемената за тврдњу да је „текстове-памфлете“ и „пасквиле против модерне поезије“ Пандуровић објављивао у Мисли и Прейороgy, ${ }^{9}$ то никако не стоји када су у питању његови текстови у Проірресу. Закључак овог Пандуровићевог текста, међутим, био је донекле изненађујући. Он је недвосмислено налагао да српски књижевници морају настојати да се поведу за хрватским, јер „хрватска књижевност представља знатно бољи принос нашој књижевности.“

3.

Ако би се могле издвојити најважније упоришне тачке у уређивачкој политици листа Проірес, биле би то две непорециве и једнодушно прихваћене стајне тачке, и два питања око којих су сами сарадници листа ломили копља.

Кад је у питању прво непорециво опредељење и власника, и уредника, и сарадника овога листа, онда је то непомирљиво опозиционарство према влади, оличено у критикама и њене унутрашње и њене спољне политике. Указивало се на недостатак демократије у друштву ${ }^{10}$ на то да се државом више не може управљати као „маленом Србијом пре рата“"11 на то да се узори имају тражити у младим демократијама попут Чехословачке, ${ }^{12}$ те да власт мора бити стриктно подељена између Круне и Парламента. ${ }^{13}$ Најдаље је у својим текстовима у овом правцу ишао главни уредник Драгиша Васић, не либећи се да напада монархију као највећег кривца за лоше стање у држави и да чак напомиње како „неће проћи много времена

9 Г. Тешић, нав. дело, 71.

10 С. Пандуровић, „Слободна конституанта“, Проірес, 1920, I, 9, 1.

11 Душан С. Николајевић, „Велика држава“, Проірес, 1920, I, 3, 1.

12 „Чехословачка демократија“, Проірес, 1920, I, 24, 1.

13 Д. С. Н., „Куда идемо“, Проірес, 1920, I, 29, 1. 
док се не покаже нужност неког другог система владавине“, 14 очигледно исказујући републиканске тенденције. У критици спољне политике владе сарадници Проіреса били су још оштрији, немилосрдно извргавајући руглу учешће Пашића и Трумбића на мировној конференцији у Паризу: „Југославија je, вођена на конференцији од ове двојице, прошла као Дубровник за време земљотреса. "15 Такође је осуђиван став владе према сукобу Пољске и совјетске Русије. Аутор тога чланка тврдио је да „док је на страни Совјетске Русије данас сва словенска мисао“, дотле „представници југословенског народа су неспособни да воде самосталну и стваралачку политику, па на нашу срамоту подржавају Пољску. ${ }^{\text {"16 }}$

Друга неупитна тенденција листа била је негација национализма и сваке шовинистичке ускогрудости. То чак није било толико диктирано потребом за зближавањем са народима с којима се тек ступило у државну заједницу, иако је, наравно, било и тих мотива (видели смо да се хрватска књижевност узимала за углед и узор коме треба тежити), колико је бивао афирмисан интернационализам и космополитизам. Иако је већ у првом броју Проіреса Тин Ујевић истицао да се књижевници не требају слепо поводити за „туђим књигама“ и европским узорима, те да „западни интелектуализам мало говори југословенском осећању“, 17 овакви ставови били су спорадични. Када је апосторофирао „сјај Младих“ у југословенској литератури, Ратко Парежанин видео је њихову моћ у томе што су се водили идејом „свечовечности“: „Разумљив нам је и наш је Леонардо као и Достојевски, Достојевски као и Шекспир, Шекспир као и Есхил, Есхил као и Уитмен, Уитмен као и Његош, као што нам је разумљив, и брат нам је, човек са Мадагаскара, или из Москве, Новог Зеланда, Дубровника, Хамбурга, Марсеља, или са кога било другог дела и места ове Планете." ${ }^{\text {"18 }}$ И у политичком и у културном дискурсу тражиле су се споне са

\footnotetext{
14 Драгиша Васић, „Бацајте ордење“, Проірес, 1920, I, 48, 1.

15 С. П., „Наши смртници“, Прогрес, 1920, I, 5, 1.

16 Момир Николић, „Поводом Пољске“, Прогрес, 1920, I, 24, 1.

17 Августин Ујевић, „За обнову срдаца“, Проірес, 1920, I, 1, 2.

18 Р. Парежанин, „Ми и они“, Проірес, 1920, I, 108, 2.
} 
Европом, а још више са Совјетском Русијом и Сједињеним Америчким Државама, као тзв. младим заједницама. Занимљиво је да су најубојитије антинационалистичке чланке писали књижевници који ће само деценију касније постати највеће апологете национализма и расистичке теорије, па и фашизма, што ће посведочити и својим ангажманом за време окупације током Другог светског рата. Тако је Светислав Стефановић у Проїресу писао да „изгледа сасвим излишно, дане кажемо депласирано, говорити о задовољењу национализма у пуном јеку највеће светске политичке и економске револуције /Октобарска револуција; прим. Б. Ђ./ коју је досад историја записала." 19 А Ратко Парежанин, који ће постати истакнути члан Љотићеве организације „Збор“, тада се у Проїресу оштро обрушавао на Марка Цара и његову тезу о „хуманитарном национализму“, тврдећи да таквог национализма нема и да је сваки национализам „зао и погрешан“.20

У том погледу, као узор узимане су Сједињене Америчке Државе, у којима се видела најуспелија духовна и културна синтеза Истока и Запада. Оптужујући у горким стиховима Европу: „Што си нам дала, блуднице стара?/ Лудницу, касарну, топове и цара“ - Бошко Токин је „прави Запад“ нашао у Америци, тврдећи да су Витмен и Чаплин „изворни експресионисти “. ${ }^{21}$ У још знаковитијем, изузетно аналитички писаном чланку, ${ }^{22}$ Токин је рашчланио амерички културни образац и указао на „врхове“ те културе. Но, читав овај текст јесте апологија у славу моgерности $и$. Наиме, поред свега што је потцртао као најзначајније особине највећих личности америчке културе - Поа, Витмена и Чаплина, Токин је нашао једну заједничку црту код све тројице - смисао и осећај за онострано! Тако је Едгар Алан По „први стваралац оног модерног смисла за надреалност“, који је схватио да „с оне стране је дубок живот. Волт Витмен, поред тога што је осетио

19 Светислав Стефановић, „Нова Европа’ и Нова Европа“, Проі̄pec, 1920, I, 93, 2.

20 Ратко Парежанин, „Марко Цар redivivus“, Проіррес, 1920, I, 111, 2-3.

21 Бошко Токин, „Експресионизам Југословена“, Проірес, 1920, I, 109, 1.

22 Бошко Токин, „U.S.A. = Poe, Whitman, Chaplin“, Проїpec, 1920, I, 128, $2-4$. 
„могућности које нова земља крије у себи“, имао је осећај „за оно што је мање видљиво, сакривеније.“ И Чаплин „иде даље у истраживању човека“, па и он, попут Поа и Витмена, „износи оно што је било невидљиво у дубинама.“ Све ово су типичне одлике модерности коју Токин примећује и у југословенској култури, због чега она треба да се ослања на америчку, док „остало човечанство гуши се и стоји.“

Међутим, најснажније се ово негативно одређење према национализму у Проіресу исказало у односу према албанском народу и осуди државне политике према њему. Године 1920. у јеку је била побуна Албанаца на Косову и у западном делу Македоније. И у другим дневним листовима тога времена, попут Политиике и Правgе, било је спорадичних гласова отпора суровом опхођењу према тамошњем албанском народу, али је такав тон у Проіресу био доминантан и неупитан. Албански народ видео се као жртва погрешне државне политике, и апеловало се на Србе као историјску нацију да пруже руку онима са којима им је било суђено живети. Истицана је државотворност албанског народа и осећај оданости оној држави у којој живе: „У Арнаутлуку нас чекају јучерашњи непријатељи и, дамо ли им своју љубав, они ће постати снажни грађани снажне државе.“1

Драгиша Васић је у аналитичком тексту указао на сличности Срба и Албанаца, налазећи међу њима спону у жудњи за слободом и непрестаној борби за част и достојанство. Кривицу за антагонизам без задршке је сваљивао на српске власти: „Ми смо у скорој прошлости /мисли на Први балкански рат; прим. Б. Ђ./ према овом народу грешили. Али не ми, не народ, већ наши политичари... Својом политиком они су нас водили једном вештачком раздору између двају народа, који имају готово све услове да пријатељски живе. Они су ишли ка апсурду да од Срба, народа који се вековима борио и бори за слободу, начине завојевача.“2

Слично је писао и Душан Николајевић, сећајући се помоћи Есад-паше Топтанија пружене избеглој српској војсци током повлачења преко Албаније. Први балкански

1 Д. С. Николајевић, „Арнаути“, Проірес, 1920, I, 15, 1.

2 Драгиша Васић, „Југославија и Арбанија“, Проірес, 1920, I, 40, 1. 
рат Николајевић је видео само делом као ослободилачки, а у односу према Албанцима несумњиво освајачки и империјалистички: „За време балканског рата ми смо били сурови освајачи /подвукао Б. Ђ./ над тим племеном. Али када је дошао наш слом, наша џиновска трагедија, и када је војска остављала земљу и кроз арбанске урвине и кланце тражила излаз на ваздух, на сунце, Арнаути нам нису вратили жиг за срамоту.“ ${ }^{“ 3}$

Први пут неко се усудио рећи да су Срби „просипали крв деце Арнаутлука“, и то нимало није могло бити пријатно владајућим круговима. Злочини које су Срби вршили над Албанцима 1912. године у Проіресу су изједначавани са злоделима која је, у сламању побуне Албанаца, те 1920. године вршила жандармерија и војска нове државе. Сарадници Проїреса нудили су други пут, пут помирења и сарадње са албанским народом и његовим представницима. Станислав Винавер отворено је поручивао: „На Косову ври, ври, пре свега кривицом неспособнога центра, недораслог и несавесног. “" Винаверови извештаји о побуни Албанаца примани су као посебно значајни, јер су долазили од очевица и невољног учесника у сламању те побуне, противзаконито мобилисаног, јер га је након Првог светског рата лекарска комисија ослободила војне обавезе. Још лицемерније је било то што је Винаверу, као и многим другим мобилисаним резервистима, у војној буквици стајало да се упућују на „вежбу“ (званична државна пропаганда све време је негирала да у борби са албанским побуњеницима учествује војска, већ само жандармерија). Да је у основи за Винаверову мобилизацију лежала казна за његово политичко деловање, па и за написе у Проіресу, не говори само Винавер, него је о томе причао цео Београд. То у свом сећању на Винавера тврди и Милан Јовановић Стоимировић, који износи мишљење да је Винавер послат на Косово са јасном надом власти да ће тамо погинути: „Негде око 1920, Винавер је са Драгишом Васићем и Момиром Николићем издавао врло опозициони лист „Прогрес“. Углавном, они су жестоко и храбро нападали

3 Д. С. Н., „Есад паша“, Проірес, 1920, I, 33, 1.

4 Станислав Винавер, „Арнаутска побуна: заблуде г. Министра Војног“, Проірес, 1920, I, 71, 2. 
Петра Живковића и „белорукачку“ дворску камарилу, борећи се и са полицијом и са судским тужиоцем. У то време су се у Јужној Србији јавили качаци. Белорукци су, вероватно заједно с полицијом, решили да Винаверу дохакају, те су га позвали као резервног официра на „вежбу“ и послали га у „југословенски Сибир“" (како је Васић крстио Косово и Метохију). Винавер је имао са редовним трупама да се бори против Арнаута и да свакако падне у тој борби. Он је дошао негде око Призрена и био откомандован „на терен“. Шта је тамо радио, то Бог једини зна, углавном он се после шест недеља вратио у Београд жив и здрав. Тане га није било!“"5

Стога није чудно што је Винавер у Проіресу указивао на корупцију у војсци, на злоупотребу у политичке сврхе, на нечовечан однос према Албанцима, те на губљење угледа војске у народу: „Одашиљући све напредне и одушевљене младе људе у војску без реда, без система, без плана, г. Министар Војни ${ }^{6}$ је био и у томе доследан ономе генералскоме менталитету, који смо тако добро имали прилике запазити на Крфу: да је војска робија, Сибир за непокорне, и да је највећа награда која се некоме може указати, ослобођење од те војске. “7 Винавер је, међутим, отишао и даље, сведочећи о изразито расистичком дискурсу када је био у питању однос српских (југословенских) власти, па и елите, о Албанцима: „Они су о Арнаутима говорили као о дивљим зверовима које се хвата са највећим тешкоћама. Све их треба побити. Оставити само децу до 7 година. Они су затрли Српство. Право је и њих да не буде. ${ }^{\text {" }}$

5 Сећање Милана Јовановића Стоимировића на Винавера чува се у Стоимировићевој заоставштини у Рукописном одељењу Матице српске у Новом Саду.

6 У тадашњој влади Миленка Веснића, као и у претходној и потоњој (све до смрти), министар војске и морнарице био је Бранко Јовановић (1868-1921), генерал који је био један од истакнутих официра, припадника тзв. Беле руке, поверљив човек и експонент генерала Петра Живковића, са којим је учествовао у Мајском преврату и са којим је организовао истрагу против Аписа и осталих црнорукаша на Солунском процесу.

7 Станислав Винавер, „Арнаутска побуна: заблуде г. Министра Војног“, Проірес, 1920, I, 71, 2.

8 Станислав Винавер, „Умирење Арбанаса“, Проірес, 1920, I, 75, 2. 
Однос према Октобарској револуцији и новој совјетској држави, али и однос према револуцији као политичкој и друштвеној чињеници, прилично је јасно поделио сараднике Проіреса у два табора. Много мање је, међутим, било оних који су заступали идеју постепених реформи у друштву и осуђивали револуцију као „диктатуру масе или класе“.9 Поред Душана Николајевића као једног од уредника, те Симе Пандуровића као власника листа, чије смо негативне ставове о револуцији већ представили, појавило се тек још неколико критичких текстова о бољшевизму, махом непотписаних.

Много је више било у Проіресу текстова у славу Октобарске револуције и у част совјетске државе. Тон оваквим написима давао је други уредник, Драгиша Васић, али у почетку је најекспониранији апологета комунистичке револуције био Светислав Стефановић. Он је писао о совјетској револуцији као политичком чину, али је у њој видео и знак духовног и културног преображаја, симбол модернизације и превазилажења ускогрудог национализма. Његове похвале револуцији кореспондирају са манифестним текстовима у одбрану модерног песништва. Као што се у својим критичким, манифестним текстовима залагао за апсолутну слободу у књижевности као услов за стварање нових вредности, ${ }^{10}$ тако је у друштвеном смислу револуцију видео као пут до те апсолутне слободе. Она може да донесе „нове вредности“, а руски народ показао је да „има унутрашње силе“ да се стави „на чело светске историје“ и да те нове вредности изнедри. ${ }^{11}$

Врхунац, у овом смислу, представља Стефановићев апологетски текст За руску револуцију, који је објавио у два наставка. ${ }^{12}$ Најважнији дискурс овог Стефановићевог текста јесте свесловенски. У његовом поимању ствари, руска

9 С. Пандуровић, „Диктатура“, Проірес, 1920, I, 28, 2.

10 Г. Тешић, нав. дело, 255.

11 Светислав Стефановић, „Нова Европа' и Нова Европа“, Проірес, 1920, I, 93, 2.

12 Светислав Стефановић, „За руску револуцију“, Прогрес, 1920, I, 108, $1 ; 109,1$. 
револуција је антиимперијалистичка и антихришћанска, а „задаћа словенства је да сруши и уништи два тешка и страшна наследства Рима - империјализам и хришћанство.“ Ако је Исус уопште постојао, он се сада, са револуцијом, враћа међу људе као „побуњени Христос“ - Лењин! Потом Стефановић руску бољшевичку револуцију доводи у везу са српском револуцијом, тј. Првим српским устанком, тврдећи да „негирањем Руске револуције, ми би изгубили оправдање за своју сопствену револуцију, негирали би себе сама.“ Карађорђе је, у таквом виђењу, Лењинов претеча. Срби су 1804. године пробудили Балкан, а Руси 1917. године Словене, а можда и цели свет. У другом делу своје расправе, Стефановић је исправно закључио да је револуцију убрзао светски рат (иако би она, сматра Стефановић, неминовно наступила), али да је зато Октобарска револуција једина добра последица тога рата. Оно што је за Стефановића, међутим, било најважније, јесте то да је комунистичка револуција представљала не само политички, него и етички и културни преврат: „Шта културно и морално високо данас представља Запад? Ништа. А Русија? Све. У најмању руку, покушај стварања новог човека и новог друштва."Стефановић је у руској револуцији видео ону „моралну снагу“ због које треба обновити проказано русофилство: „Русофоби према старој Русији, ми према новој, младој и демократској Русији гајимо и осећамо љубав и топлину највишега русофилства. ${ }^{\text {"13 }}$

И Станислав Винавер исказивао је у Проіресу симпатије за бољшевичку револуцију, као повратник из Русије из прве руке упућен у тамошње догађаје. ${ }^{14}$ Под псеудонимом Само

13 Dr Стеф., „Словенски Север“, Проірес, 1920, I, 15, 1.

14 Уосталом, Винавер је у то време у Београду држао јавна предавања о Русији и бољшевичкој револуцији, како сведочи и Милан Јовановић Стоимировић. „Једнога дана, он је заказао некакво предавање о Русији у дворани Касина; сала је била дупке пуна, али је он говорио шетајући преко рампе и сваки час загледајући у неку цедуљу, што је остављало ружну слику и нервирало свет; ускоро је између публике и њега дошло до свађе; неки су му добацивали да је боље требао спремити своју „говоранцију“ пре него што је уопште изишао на подијум; други су се посвађали међу собом, јер су једни хтели да пажљиво прате излагање тога младог конферансијеа, док су други 
Толко он је, иначе, писао ироничне и убојите инвективе против владе и интелектуалаца који су „кадили владајућима“, 15 али је обавештавао и о претученим комунистима (у то време, не треба заборавити, Социјалистичка радничка партија комуниста била је легална организација), ${ }^{16}$ а исто тако указивао на „неминовну победу бољшевизма“ у грађанском рату у Русији, тврдећи - испоставиће се с правом - да „постаће неизбежно за савезничке владе брзо закључење мира са Русијом. ${ }^{\text {“17 }}$

Са потпуним преузимањем уредничке палице од стране Драгише Васића, овај пробољшевички дискурс потпуно ће превладати, ${ }^{18}$ што ће довести до све чешћих забрана листа, о чему је и сам Васић писао. ${ }^{19}$

5.

Као што је већ истакнуто, лист Проїрес био је специфичан по ономе што бисмо данас назвали плурализмом идеја. То

били за то да „кваре“. Винавер је подвикнуо: „Молим вас, без галаме! Коме се не слуша, нека иде напоље!“ Неко је довикнуо: „Врати ми паре које сам дао за улазницу, па идем!“ Винавер му је рекао: „Дођите да вам дам ваше паре, па се чистите“ - али кад је почео да преврће џепове, у њима није било ни цвоњка. Настао је општи смех. Добацивали су и поруге предавачу. Он је на двоје на троје завршио своје предавање, из кога се није могло да разазна ни шта је он видео и доживео у Русији, нити шта он мисли о њеној будућности. Али је било очиілеgно gа он није мислио рђаво о руској револуцији и gа није жалио сииару изарску Русију/подвукао Б. Ђ./. Отуда се о њему мислило да је левичар, и то је мишљење остало све до 1925.“ Сећаюе Милана Јовановића Сйоимировића, Рукописно одељење Матице српске.

15 Нарочито жесток био је напад на Војислава Јовановића Марамбоа, када је Винавер тврдио да се Војислав Јовановић, као владин службеник, „одвојио и отуђио од Марамбоа“. Видети: Проірес, 1920, I, 109, 1.

16 „Слобода мисли на општинским добошима“, Проірес, 1920, I, 3, 1; „Срамота Београда“, Проірес, 1920, I, 25, 2.

17 „Бољшевици држе петролеум“, Проірес, 1920, I, 3, 1.

18 Посебно су, у том погледу, индикативни и провокативни текстови самог Драгише Васића:; „За руску револуцију“, Проірес, 1920, I, 137, 1; „Неразумевање револуције“, Проїрес, 1920, I, 138, 1.

19 Д. Васић, „Жестоко насиље београдске полиције“, Проірес, 1920, I, 73, 2; „Реч нашег уредника“, Проірес, 1920, I, 74, 1. 
се најбоље види у текстовима из књижевности и о књижевности. Еклектицизам који се примећује није постојао ни у једном другом гласилу, а поларизација на књижевној сцени допринеће томе да то више и не буде могуће. Иако је помало претерано Проірес (који је, уосталом, превасходно био политички лист) сврставати међу авангардне листове ${ }^{20}$ опет је тачно да је у њему био окупљен велики број књижевника који су припадали кругу тзв. младих, модерних и антитрадиционалистички настројених стваралаца. Али - и у томе је специфичност уређивачке политике овога листа - у њему су истовремено писали и изразити представници традиционалистичке струје, представници онога што се назива „конзервативном критиком“. 21 Тако се често дешавало да исти књижевник који је своје модернистичке и авангардне текстове објављивао у Проіресу (попут Винавера, Црњанског, Токина) већ у неком од следећих бројева потпадне под удар жестоке критике с другог краја књижевне сцене (коју су оличавали, уз Пандуровића, пре свега Ратко Парежанин и Синиша Кордић). Оваква врста уређивачке политике представљала је прави спецификум.

Тако је Винаверов чланак Црнански и критиччари ${ }^{22}$ заиста био „први у серији Винаверових полемичких текстова који се уклапају у одбрану авангарде двадесетих година“,23 али иако је Винавер у њему полемисао и са И. Димитријевићем, Т. Прпићем, и нешто блаже са Пандуровићем, ${ }^{24}$ овај Винаверов текст је пре свега одговор на два оштра напада на Црњанскијеву књигу Приче о мушком, објављена нешто раније управо у Проіресу. Први је текст Синише Кордића, у коме он уопште не анализира књигу, већ директно напада Црњанског као човека, који је „ништаван, бедан, невредан“, „испод најобичнијег човека, нашег сељака“, и који „у ствари не постоји. “25

20 Станислава Бараћ, Авані̄арgна „Мисао“, Институт за књижевност и уметност, Београд, 2008, 15.

21 Г. Тешић, нав. дело, 326.

22 Станислав Винавер, „Црњански и критичари“, Проїрес, 1920, I, 95, 2; 96, 2-3.

23 Г. Тешић, нав. дело, 287.

24 Детаљну анализу овог Винаверовог текста видети у: Г. Тешић, нав. дело, 287-289.

25 Синиша Кордић, „Поводом најновије књиге г. Милоша Црњанског“, Проірес, 1920, I, 54, 2. 
На Кордића се надовезао и Тин Ујевић, који је младе песнике оптужио да се сувише поводе за европским трендовима, уместо да „жуде за својим, апсолутно новим свемиром.“" Поменуо је Косора, Миличића, Бешевића и Винавера, али главнину његовог текста представља беспоштедна критика Прича о мушком, књиге која је „пуна незрелих ствари“, јер је Црњански показао да има „прејак реторички темперамент, а да нема детаљне објективности и хладнокрвности. “26

Оваквих полемичких „дозивања“ било је још у Проіресу. Тако, као директна последица напада Ратка Парежанина на њега, ${ }^{27}$ настаје Винаверов текст у одбрану сопствене пое-

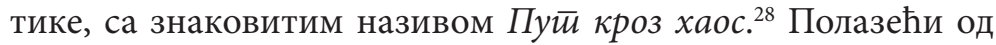
основне тезе да су иза Скерлићеве искључивости и ускогрудости Богдана Поповића остали „збрка и хаос“ у књижевном животу, и да је он својом Панйолоіијом желео да тај хаос дочара и да истакне неке елементе у актуелним књижевним стремљењима, Винавер је отишао даље од објашњења своје књиге, тј. њене одбране, пруживши аутопоетички есеј у коме је сажео све примедбе на своје књижевно стварање, али са поентом у којој инсистира на доследности сопственог ангажмана од почетка бављења литературом до тог тренутка: „Људи који ми нису никад признавали таленат, рећи ће после ове моје нове књиге, да је мој таленат у опадању. Критичари који су имали само ироничне речи, пуне пакости и злобе, за Варош злих волшебника, за Мисли, за Приче које су изгубиле равнотежу - пронаћи ће да сам у тим својим делима био веома интересантан - да би само могли констатовати да је време мојих победа прошло. Читаоци ће, навлаш се правећи глупљи него што су, опет говорити да сам ја замршен, неразумљив, и неће ме хтети читати у наивној и комичној нади да се уметност да̂ разумети брже него игра домина и пиљака „по турски“““ На крају је Винавер наговестио и даљу „беспоштедну борбу“ његове генерације против „пређашњих“ књижевника и традиционалиста: „Исто тако као што на̂с није поштедео ваш Демон, и ми за вас немамо поштеде.“

26 Августин Ујевић, „Поводом Пурића и Црњанског“, Проірес, 1920, I, $66,1$.

27 Рпн., „Фаталност“, Проїрес, 1920, I, 30, 2.

28 Станислав Винавер, „Пут кроз хаос“, Проірес, 1920, I, 107, 2 -3. 
Врхунац Винаверовог ангажмана у Проіресу свакако представља један од стубова његовог критичког ангажмана, есеј Манифести ексирресионистичке школе, објављен у шест наставака током септембра и октобра 1920. године. ${ }^{29}$ Овај Винаверов текст је подробно анализиран у нашој науци о књижевности, али овде треба истаћи да се и овај капитални Винаверов есеј реферише на претходне текстове у Проіресу, како негативно одређене према модерним тенденцијама у књижевности (пре свега на Ујевићев текст Бор зелен $u^{30}$ ), тако и на текстове својих истомишљеника (директно на нетом објављене чланке Бошка Токина ${ }^{31}$ и Ранка Младеновића ${ }^{32}$ ).

Најизразитију апологију модернизма, поред Винавера и Светислава Стефановића, пружио је, и то на врло занимљив начин, Тодор Манојловић, у свом есеју објављеном у три наставка, под називом Жена и нова йоезија. ${ }^{33}$ Писан у форми дијалога мушкарца и жене $(\mathrm{OH}$ и $\mathrm{OHa})$, овај есеј представља мушку одбрану женске књижевности. Јер, у овом есеју жена је скептик, убеђена да је жена као песник нужно парадоксална чињеница, односно да се жена, да би се остварила у књижевности, мора одрећи свог женског бића и постати „мушкобања“: „Женска литература и уметност - благо речено - увек су сумњиве вредности... Поезија је једна мушка ствар.“ Мушкарац, напротив - а то је несумњиво став самог Манојловића - сматра да је равноправност жене нужна у сваком сегменту друштвеног ангажмана, па и у књижевности. И управо зато жене би требало да прве прихвате нове, авангардне тенденције, да буду револуционарне и да се не плаше промена: „Препорођај поезије је услов за рађање једне нарочите, чисте, женске поезије“ - а она би морала бити „модерна и ангажована“, са сензибилношћу која недостаје мушкарцима.

29 Станислав Винавер, „Манифест експресионистичке школе“, Проі̄рec, 1920, I, 114, 2-3; 115, 2-3; 116, 2-3; 124, 2-3; 126, 2-3; 130, 2-4.

30 Августин Ујевић, „Бор зелени“, Проірес, 1920, I, 113, 2-3. У овом тексту Ујевић, користећи епску метафору из песме Косовка gевојка, говори о „јаловости“ младих писаца.

31 Бошко Токин, „Експресионизам Југословена“, Проірес, 1920, I, 109, 2-3.

32 Ранко Младеновић, „Космичка лирика“, Проірес, 1920, I, 110, 2-3.

33 Тодор Манојловић, „Жена и нова поезија“, Проірес, 1920, I, 15, 2; 16, $2 ; 17,2$. 
Несумњиво је да је Манојловић исписао један, по многим елементима феминистички есеј, као мушкарац схватајући да модерност у друштву, па и у књижевности, жене морају не само прихватити, већ и промовисати. Овај Манојловићев есеј би без сумње могао бити објављен и у Женском йокрет̄у који је покренут само месец дана раније, јер се по свом феминофилству сасвим уклапао у тај контекст. Иако уређивачка политика Проіреса није посебно инклинирала феминофилном (уосталом као ни мизогином) дискурсу, Манојловићев текст претходио је сличнима у Новој Евройи и Мисли. Усуђујемо се да претпоставимо да је овакав текст - уз још два-три слична - био могућ зато што је власник Проіреса био Сима Пандуровић, који је нешто доцније феминофилни дискурс подржавао и промовисао као уредник Мисли. ${ }^{34}$

6.

Током шест месеци излажења, лист Проірес био је под непрекидном паском власти и тужилаштва. Колико је сад могуће утврдити, била су забрањена чак двадесет четири броја Проіреса! Због тога су се и оглашивачи повлачили, а то је изазивало и тензије међу власницима, уредницима и сарадницима. Било је јасно да и многострани, и веома демократски, приступ одређеним политичким и културним темама постаје све мање могућ, и да се културна сцена у новоствореној држави све више поларизује. Сукоб власника Симе Пандуровића са Божом Николајевићем октобра 1920. године само је убрзао гашење листа. Међусобно се оптужујући за издају током окупације у Првом светском рату, ${ }^{35}$ овај сукоб довео је до тога да Божин брат Душан Николајевић поднесе оставку на место једног од уредника Проїреса, а одмах затим

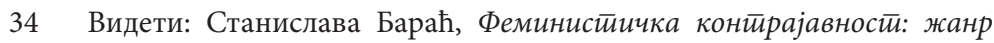

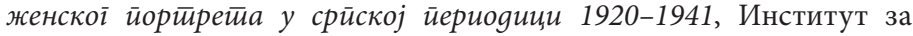
књижевност и уметност, Београд, 2015, 111.

35 О овоме видети: Бојан Ђорђевић, „Чија се рука машила непријатељске браве: о „издаји“ интелектуалаца у Првом светском рату“, ЛИК, 2018, IV/5, 74-78. 
власнички удео у листу повукао је Пандуровић. Драгиша Васић остао је сам и успео да одржи лист још само месец дана. У броју од 7. новембра наговестио је да ће лист убудуће излазити као недељник. Међутим, 15. новембра 1920. године изашао је последњи, 143. број. Тако се угасио лист који је био посебан, и који је, упркос своје политичке суштине, остао као трајна вредност у нашој културној историји, с обзиром на то да су се у њему, и око њега, окупила нека од највећих имена српске и хрватске књижевности. Уосталом, поред свих наведених манифестних, критичких, па и памфлетистичких текстова, довољно је рећи да је у Проіресу Милош Црњански објавио свој Рај, ${ }^{36}$ Станислав Винавер Громобран свемира, ${ }^{37}$ Драгиша Васић ${ }^{38}$ и Станислав Краков ${ }^{39}$ своје приповетке, a Сибе Миличић писао ликовну критику. ${ }^{40}$ Већ и по томе, Проірес остаје незаобилазан у истраживању наше модернистичке и авангардне уметности.

\section{ИЗВОРИ}

Проїрес (Београд). Год. 1920, бр. 1-143.

Сећаюа Милана Јовановића Сйоимировића, Рукописно одељење Матице српске.

\section{ЛИТЕРАТУРА}

Бараћ, Станислава (2008). Авані̄арgна „Мисао“. Београд: Институт за књижевност и уметност.

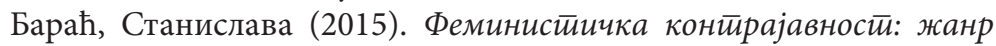

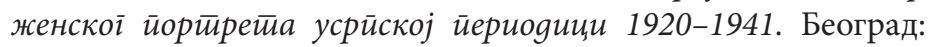
Институт за књижевност и уметност.

36 Милош Црњански, „Рај“, Проірес, 1920, I, 25, 2; 26, 2; 27, 2; 28, 2; $29,2$.

37 Станислав Винавер, „Громобран Свемира“, Проірес, 1920, I, 135, 2-4.

38 Драгиша Васић, „Јагње“, Проіррес, 1920, I, 4, 2; Драгиша Васић, „Чују се топови“, Проірес, 1920, I, 19, 2.

39 Станислав Краков, „Освета“, Проірес, 1920, I, 10, 2; 11, 2; 12, 2; 13, 2; 14,2 .

40 С. М., „Из уметничких кругова“, Проіррес, 1920, I, 3, 2; Сибе Миличић, „Изложба Ладе“, Проірес, 1920, I, 5, 2; С. М., „Изложба покојног Косте Миличевића“, Проірес, I, 8, 2; С. М., „Посмртна изложба Косте Миличевића у II београдској гимназији“, Проірес, 1920, I, 16, 2. 
Ђорђевић, Бојан (2018). „Чија се рука машила непријатељске браве. О „издаји“ интелектуалаца у Првом светском рату“. ЛИК, IV/5; стр. 55-81.

Tešić, Gojko (1991). Srpska avangarda u polemičkom kontekstu. Novi Sad: Beograd: Svetovi: Institut za književnost i umetnost.

\section{Бојан М. Ђорђевић}

\section{КАД СУ КОНТРАРЕВОЛУЦИОНАРИ ПРИЗИВАЛИ РЕВОЛУЦИЈУ: КУЛТУРНИ ДИСКУРС ДНЕВНОГ ЛИСТА ПРОГРЕС (1920)}

Када бисмо на једном месту донели списак српских и хрватских књижевника и културних радника који чине: Сима Пандуровић, Драгиша Васић, Душан Николајевић, Тодор Манојловић, Тин Ујевић, Милош Црњански, Ратко Парежанин, Станислав Винавер, Станислав Краков, Синиша Кордић, Светислав Стефановић, Ранко Младеновић, Растко Петровић, Бошко Токин, Сибе Миличић - тешко бисмо могли избећи примедбе за недопустиви еклектицизам, за произвољно повезивање књижевника који су и својим животом, и својим светоназорима, и својим поетикама у много чему различити, а често и антиподи. Могло би се, штавише, даље рећи да би се њихова имена, овако скупно узета, могла наћи једино у каквој антологији, па и онда би се приређивач такве антологије могао оптужити за некритичност и недостатак доследног критеријума. Па ипак, у једном тренутку, током шест месеци, од маја до новембра 1920. године, сви ови књижевници заиста су се нашли заједно, окупљени око дневног листа који је утемељен као независно политичко гласило, али који је од почетка имао много већи утицај на културни живот у тек формираној и још до краја неуобличеној Краљевини Срба, Хрвата и Словенаца. Уосталом, управо то што су прилике у земљи биле још увек несређене, што се водила полемика о карактеру власти и државне организације, о политичком устројству - све то је омогућило да постоји, макар и накратко, овакав лист који ће, упркос основама уређивачке политике и главном тону, постати место слободног сучељавања различитих ставова 
о најразноврснијим питањима политичког и културног живота. Само у таквим околностима, и са овако широком лепезом углавном млађих сарадника, могла се и нападати и бранити државна политка, и славити и осуђивати Октобарска револуција, и заступати и оштро критиковати модернизам у књижевности и уметности, а о истим књижевним текстовима писати и афирмативно и негаторски. Већ и по томе, Проіррес остаје незаобилазан у истраживању наше модернистичке и авангардне уметности. 